Thoraxkirurgi

Haram, Per Magnus

Solholm, Atle

Urologi

Almås, Bjarte

Halland, Adrian

Øre-nese-halssykdommer

Abrahamsen, Anne Beate

Uppheim, Alexander

$\emptyset$ yesykdommer

Sauesund, Ellen Steffenssen

Godkjent i sentralstyrets møte 15. januar 2014: Kompetanseområdet i alders- og sykehjemsmedisin Godkjent ble:

Fiske, Mari

Hannisdal, Gunvor

Sanaker, Harald

Vangsnes, Kari

Åmdal, Gerd Torbjørg

Godkjent i sentralstyrets møte 13. februar 2014: Kompetanseområdet i alders- og sykehjemsmedisin Godkjent ble:

Aune, Anne

Enoksen, Kjellaug

Fosse, Anette

Geelmuyden, Alexander

Husebø, Bettina

Huurnink, Aart

Lichtwarck, Bjørn

Lyngmo, Inga Margrete

Nitter, Wenche Hilde

\section{UTVALGT ARBEIDSSTED}

\section{Vestre Viken}

Vestre Viken ble etablert 1. juli 2009 da Ringerike sykehus, Drammen sykehus, Bærum sykehus og Kongsberg sykehus ble slått sammen. Lier og Blakstad psykiatriske sykehus, i tillegg til Hallingdal sjukestugu, 17 ambulansestasjoner og en rekke andre behandlingssteder er også en del av Vestre Viken.

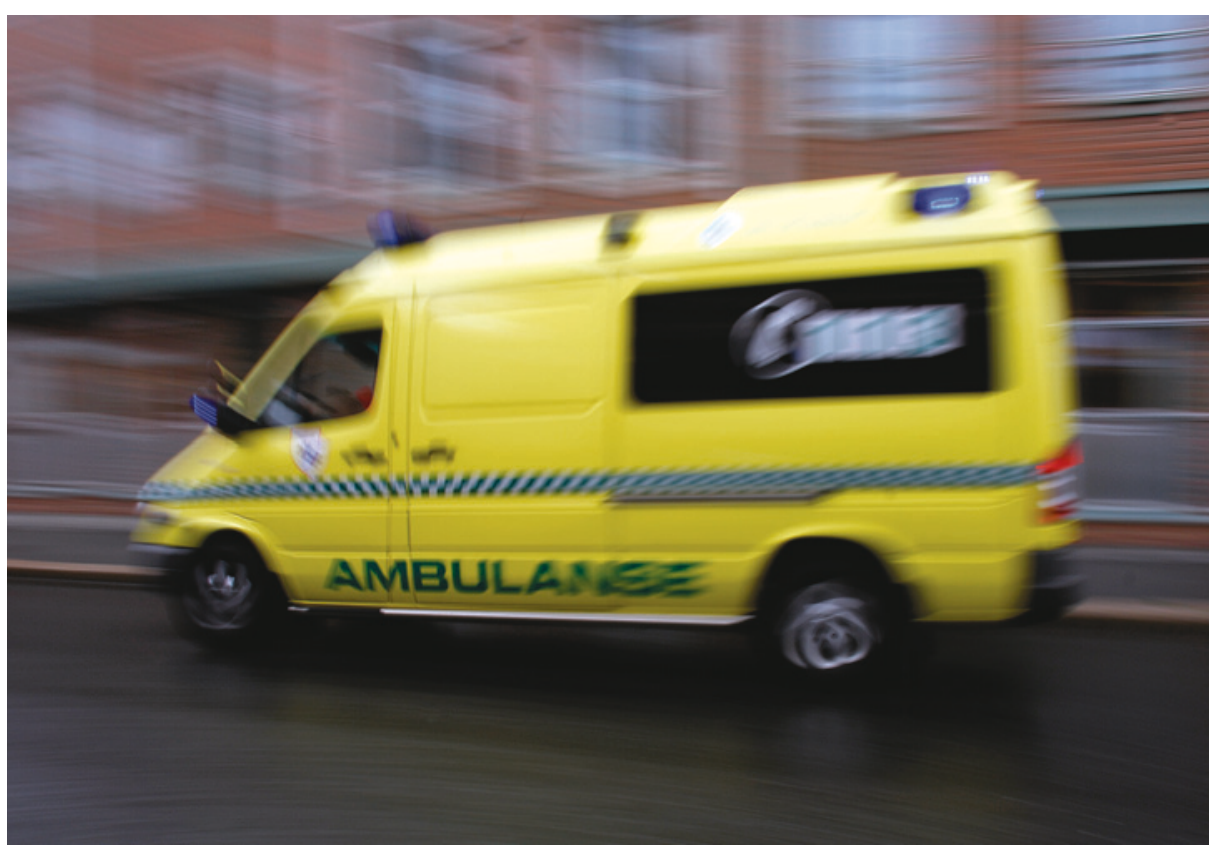

Foto: Vestre Viken

Til sammen driver foretaket sin virksomhet i 146 bygg som utgjør mer enn 315000 kvadratmeter.

Foretaket har et samlet budsjett på nærmere 7,5 milliarder kroner. Det har over 9500 ansatte og samarbeider tett med primærhelsetjenesten i kommunene for å levere sykehus- og spesialisthelsetjenester til 465000 mennesker i 26 kommuner.

Hvert år fødes over 5000 barn hos foretaket. Sykehuset har ca. 375000 somatiske og over 200000 psykiatriske pasienter til behandling årlig, med over 575000 somatiske konsultasjoner, 330000 bildediagnostiske undersøkelser og 365000 kirurgiske inngrep hvert år.

Vestre Viken har som mål å levere gode, trygge og likeverdige helsetjenester til alle som trenger det, når de trenger det. Foretaket er en solid arbeidsplass med mye variasjon og flere forskjellige arbeidslokasjoner. Noen av de største arbeidsplassene er Klinikk for psykisk helse og rus, Drammen sykehus, Bærum sykehus, Ringerike sykehus og Kongsberg sykehus, i tillegg til et nytt og større områdesykehus som foretaket skal bygge i Buskerud.

Psykisk helse og rus er den største klinikken i Vestre Viken og har et av Norges mest komplette tilbud innen fagfeltet. Bærum sykehus og Drammen sykehus er spesialsykehus som i hovedsak behandler pasienter med somatiske lidelser. Drammen sykehus er det største somatiske sykehuset i Vestre Viken. Ringerike sykehus er et lokalsykehus med akuttfunksjon og et stort ansvarsområde i Buskerud. Kongsberg sykehus er et lokalsykehus og samarbeider tett med kommunene for å levere et robust og fremtidsrettet helsetilbud til befolkningen. 